\title{
HLA-Types, C-Peptide and Insulin Antibodies in Juvenile Diabetes*
}

\author{
J. Ludvigsson, J. Säfwenberg and L. G. Heding \\ Departments of Paediatrics, Linköping University, Linköping, and Blood Centre, University of Uppsala, Uppsala, Sweden, \\ and Novo Research Institute, Copenhagen, Denmark.
}

Summary. HLA-types were determined in 102 juvenile diabetics. HLA-B8 was found in 39 patients (RR 2.64; $p<0.01$ ) and HLA-BW15 in 32 patients (RR 1.33 ; n.s.). HLA-B7 was found in 14 patients (RR $0.40 ; p<0.05$ ). There were no correlations between HLA-B8 or BW15 and family history of diabetes, occurrence of infection before onset of diabetes, ketonuria at onset or the age at onset of diabetes. Serum C-peptide, insulin binding capacity of IgG and total serum insulin, IRI, were determined in 94 patients who had had diabetes for more than two years and who were beyond the remission period. Measurable amounts of C-peptide were found in 33 patients $(34.7 \%)$. There was no evidence of a relationship between any particular HLA-antigen and the $B$-cell function except for an increased incidence of detectable C-peptide in patients with HLA-B18 and a tendency to a decreased incidence of detectable Cpeptide in patients with the combination HLA-B8, W15. Only four patients $(4.3 \%)$ were lacking insulin antibodies. HLA-BW15 positive patients had higher levels of insulin antibodies than other groups, while HLA-B7 positive patients had lower levels. The results suggest that HLA-B7 and HLA-B18 might be associated with a different and perhaps milder form of juvenile diabetes.

Key words: Juvenile diabetes, HLA, C-peptide, insulin antibodies, total IRI.

* This work was supported by the Swedish Medical Research Council no 16X-3557 and no 19X-04528, by the Swedish Diabetic Association and by the Medical Faculty, Linköping University, Sweden
The relative risk of getting insulin-dependent diabetes is increased for carriers of the HLA-antigens B8 and BW15 [1, 4, 6, 7, 8, 18, 24, 25, 26, 27, 29]. Among patients with insulin-dependent diabetes of short duration islet cell antibodies have been found more frequently in those with the HLA-DW3 antigen [23]. It has been suggested that, in patients with certain HLAantigens, infections might provoke an immune response leading to B-cell destruction $[14,24]$. The aim of this study was to examine the HLA-frequencies in children with juvenile diabetes and to relate the HLAantigens to the age at onset of diabetes, the family history of diabetes, the occurrence of infections shortly before onset of diabetes and the incidence of ketonuria on admission to hospital at the onset of the disease. We also wanted to study the relation between HLA-antigens and the persistence of measurable Cpeptide beyond the early remission period and to compare the HLA-antigens with the level of insulin antibodies.

\section{Material}

The study comprised 102 Caucasian non-related juvenile diabetics with age at onset of diabetes from 1-16 years $(7.1 \pm 3.9)$ and duration of diabetes of $1-17$ years $(6.6 \pm 3.5)$. All of the patients had been treated with long acting insulin (Lente or NPH) once or twice daily, in many cases supplemented with intermediate or shortacting insulin (Semilente, Actrapid or Regular insulin). No patients had been given monocomponent or rare immunogenic insulin at the time of the study.

C-Peptide and insulin antibodies (IgG and IRI) were determined in those 94 patients who had more than two years duration of diabetes and who were beyond the early remission period. Their age at onset 
Table 1. HLA phenotype frequencies (a) in patients with juvenile diabetes mellitus and in a non-diabetic Swedish population

\begin{tabular}{|c|c|c|c|c|}
\hline \multirow[t]{2}{*}{ HLA } & \multicolumn{3}{|c|}{102 patients } & \multirow{2}{*}{$\begin{array}{l}500 \text { control } \\
\text { a }\end{array}$} \\
\hline & $\mathbf{n}$ & $\mathrm{a}$ & RR & \\
\hline A & 28 & .275 & 1.31 & .224 \\
\hline 2 & 71 & .696 & 1.49 & .606 \\
\hline 3 & 23 & .226 & 0.62 & .318 \\
\hline 9 & 24 & .235 & 1.29 & .192 \\
\hline W25 & 5 & .049 & 1.18 & .042 \\
\hline W26 & 4 & .039 & 0.71 & .055 \\
\hline 11 & 7 & .069 & 0.69 & .096 \\
\hline 28 & 8 & .078 & 0.69 & .110 \\
\hline W19 & 12 & .118 & 0.73 & .154 \\
\hline 29 & 3 & .029 & 0.98 & .031 \\
\hline W30 & 5 & .049 & 3.72 & .014 \\
\hline W31 & - & & & .048 \\
\hline W32 & 2 & .020 & 0.35 & .055 \\
\hline B 5 & 7 & .069 & 0.78 & .086 \\
\hline 7 & 14 & .137 & 0.40 & $.284^{\mathrm{a}}$ \\
\hline 8 & 39 & .382 & 2.64 & $.190^{\mathrm{b}}$ \\
\hline 12 & 16 & .157 & 0.49 & .274 \\
\hline 13 & 5 & .049 & 1.38 & .036 \\
\hline 14 & - & & & .024 \\
\hline 18 & 9 & .088 & 1.33 & .068 \\
\hline 27 & 9 & .088 & 0.80 & .108 \\
\hline W15 & 32 & .314 & 1.33 & .256 \\
\hline W16 & 6 & .059 & 1.67 & .036 \\
\hline W17 & 3 & .029 & 0.58 & .050 \\
\hline W21 & 4 & .039 & 2.87 & .014 \\
\hline W22 & 6 & .059 & 1.89 & .032 \\
\hline W35 & 2 & .088 & 0.51 & .160 \\
\hline W37 & 2 & .020 & 0.45 & .042 \\
\hline W40 & 30 & .294 & 1.59 & .208 \\
\hline W41 & - & & & .006 \\
\hline C W1 & 3 & .029 & 0.40 & .070 \\
\hline W2 & 7 & .069 & 0.73 & .092 \\
\hline W3 & 45 & .441 & 1.18 & .400 \\
\hline W4 & 12 & .118 & 0.59 & .185 \\
\hline
\end{tabular}

Table 2. Family history of diabetes, occurrence of infection within two months before onset of diabetes, ketonuria at onset of diabetes and age at onset of diabetes in relation to HLA-types

\begin{tabular}{|c|c|c|c|c|c|c|c|c|}
\hline \multirow[t]{2}{*}{ HLA } & \multirow{2}{*}{$\begin{array}{l}\text { Total } \\
\mathrm{n}\end{array}$} & \multicolumn{2}{|c|}{$\begin{array}{l}\text { Family } \\
\text { history } \\
\text { of diabetes }\end{array}$} & \multicolumn{2}{|c|}{$\begin{array}{l}\text { Infection } \\
\text { before } \\
\text { onset }\end{array}$} & \multicolumn{2}{|c|}{$\begin{array}{l}\text { Ketonuria } \\
\text { at onset }\end{array}$} & $\begin{array}{l}\text { Age at } \\
\text { onset }\end{array}$ \\
\hline & & $\mathrm{n}$ & $\%$ & $\mathrm{n}$ & $\%$ & $\mathbf{n}$ & $\%$ & mean $\pm \mathrm{SD}$ \\
\hline B8 & 39 & 10 & 25.6 & 12 & 30.8 & 33 & 84.6 & $\begin{array}{ll}6.5 & 3.7\end{array}$ \\
\hline BW15 & 32 & 12 & 37.5 & 9 & 28.1 & 27 & 84.4 & $\begin{array}{ll}6.5 & 3.8\end{array}$ \\
\hline B8, W15 & 11 & 4 & 36.4 & 5 & 45.5 & 9 & 81.8 & $5.2^{\mathrm{b}} \quad 2.8$ \\
\hline B7 & 14 & 4 & 28.5 & 1 & $7.1^{\mathrm{a}}$ & 13 & 92.3 & 8.34 .8 \\
\hline B18 & 9 & 1 & $11.1^{b}$ & 3 & 33.3 & 8 & 88.9 & 7.12 .8 \\
\hline
\end{tabular}

\begin{tabular}{lllllllll}
\hline $\begin{array}{l}\text { All } 102 \\
\text { patients }\end{array}$ & 35 & 34.3 & 32 & 31.4 & 87 & 85.3 & 7.1 & 3.9
\end{tabular}

$\mathrm{a}=\mathrm{p}<0.05$

b $=p<0.10$ of diabetes ranged from $1-16$ years $(6.9 \pm 3.9)$ and duration of diabetes from $2-17$ years $(6.7 \pm 3.3)$. The HLA-reference group consisted of 500 adult non-related non-diabetic individuals.

\section{Methods}

Clinical data were taken from the patient records supplemented by questionnaires regarding family history.

HLA-typing was performed by the lymphocytotoxic microtechnique described by KissmeyerNielsen and Kjerbye [13]. Lymphocytes were isolated according to Thorsby [30] and Böyum [3]. The investigation included the following $34 \mathrm{HLA}$-antigens:

A: 1, 2, 3, 9, W25, W26, 11, 28, W19, 29, W30, W31, W32

B: $5,7,8,12,13,14,18,27, W 15, W 16, W 17, W 21$, W22, W35, W37, W40, W41

C: W1, W2, W3, W4

Blood for determination of C-peptide and insulin antibodies was drawn from the fasting patients prior to their morning insulin injection. Serum was stored at $-18^{\circ} \mathrm{C}$.

$C$-peptide was determined by a specific radioimmunoassay in which proinsulin is removed through binding to insulin antibodies covalently coupled to Sepharose [10]. Since most of the serum contained insulin antibodies, which have been shown to bind proinsulin, the serum was extracted at a low $\mathrm{pH}$ in the same way as described for total IRI [9] before the determination of C-peptide.

Insulin Antibodies: The binding of insulin to IgG was determined by a method according to Christiansen [5] and total immunoreactive insulin, IRI, was determined after acid extraction of serum according to Heding [9].

Statistical calculations of the relative risks (RR's) were performed with the methods described by Svejgaard et al. [28]. The chi ${ }^{2}$-test and Student's t-test were used to evaluate differences between subgroups of the material.

\section{Results}

The HLA-phenotype frequencies and relative risks are shown in Table 1. HLA-B8 was found in 39 of the 102 patients $(38.2 \%)$. This means that the RR for juvenile diabetes among HLA-B8 positive individuals is $2.64(\mathrm{p}<0.01)$. BW15 was found in 32 patients (31.4\%) with RR 1.33 (n.s.). HLA-B8 and/or BW15 was found in 60 patients $(58.8 \%)$ with RR 2.11 (p< 0.05 ). HLA-B8, W15 was found in 11 patients 
Table 3. Fasting serum C-peptide in relation to HLA-types and duration of diabetes

\begin{tabular}{|c|c|c|c|c|c|c|c|c|}
\hline \multirow{3}{*}{ HLA } & \multirow{3}{*}{ Total } & \multirow{2}{*}{\multicolumn{2}{|c|}{ Duration of diabetes }} & \multicolumn{5}{|c|}{ C-peptide $\mathrm{pmol} / \mathrm{ml}$} \\
\hline & & & & \multicolumn{2}{|c|}{$<0.04$} & \multirow{2}{*}{$\begin{array}{l}\geq 0.04 \\
\mathbf{n}\end{array}$} & \multirow[t]{2}{*}{ mean range } & \multirow[t]{2}{*}{$\mathrm{p}$} \\
\hline & & mean & $\pm \mathrm{SD}$ & $\mathrm{n}$ & $\%$ & & & \\
\hline B8 & 36 & 7.0 & 3.8 & 25 & 69.4 & 11 & $0.16(0.04-0.32)$ & \\
\hline BW15 & 28 & 7.3 & 3.5 & 22 & 78.6 & 6 & $0.18(0.04-0.34)$ & \\
\hline B8, W15 & 10 & 9.7 & 3.5 & 9 & 90.0 & 1 & 0.04 & $<0.10$ \\
\hline B7 & 14 & 7.0 & 4.5 & 9 & 64.3 & 5 & $0.63(0.14-2.30)$ & \\
\hline B18 & 8 & 6.1 & 3.8 & 2 & 25.0 & 6 & $0.13(0.06-0.25)$ & $<0.02$ \\
\hline $\begin{array}{l}\text { All } \\
\text { patients }\end{array}$ & 94 & 6.7 & 3.3 & 61 & & 33 & $0.26(0.04-2.30)$ & \\
\hline
\end{tabular}

Table 4. Insulin binding capacity of IgG (insulin antibodies) in relation to HLA-types

\begin{tabular}{lccccccc}
\hline \multicolumn{7}{c}{ IgG mU/ml } \\
\cline { 2 - 7 } HLA & Total & $<0.300$ & $0.300-2.000$ & $>2.000$ & mean & SD \\
\hline B8 & 36 & 5 & 14 & 17 & 2.544 & 2.837 \\
BW15 & 28 & $0^{\mathrm{a}}$ & 9 & $19^{\mathrm{a}}$ & 3.192 & 2.253 \\
B8, W15 & 10 & 0 & 4 & 6 & 3.115 & 2.758 \\
B7 & 14 & 3 & 9 & $2^{\mathrm{b}}$ & 1.571 & $1.499^{\mathrm{a}}$ \\
B18 & 8 & 3 & 3 & 2 & 2.235 & 3.089 \\
\hline All & & & & & & & \\
patients & 94 & 11 & 34 & 49 & 2.850 & 2.691 \\
\hline a $=\mathrm{p}<0.05$ & & & & & \\
b $=\mathrm{p}<0.01$
\end{tabular}

$(10.8 \%)$ with RR $2.76(p<0.05)$ HLA-B7 was found in 14 patients $(13.7 \%)$ giving a significantly low $R R$ of $0.40(\mathrm{p}<0.05)$. The incidence of all other HLA-types did not differ significantly from that of the reference material.

In patients with the combination HLA-B8, W15, the age at onset of diabetes was $5.2 \pm 2.8$ years compared with $7.4 \pm 4.0$ years for the rest of the patients (Table 2, $\mathrm{p}<0.10$ ). A positive family history for juvenile and/or maturity onset diabetes (parents, siblings, grandparents) was found in 35 cases $(34.3 \%)$. The frequency was the same in patients with HLA-B8 and/or BW15 as in the other groups, although it tended to be lower in patients with B18 $(p<0.10)$. A history of infection within two months before onset of diabetes was reported in 32 patients $(31.4 \%)$. Patients with HLA-B8 and/or BW15 did not show more infections preceding onset than the other groups, but in patients with HLA-B7 infection before onset was significantly less common than in the other groups $(\mathrm{p}<$ $0.05)$. On first admission to hospital at the onset of diabetes 87 patients $(85.3 \%)$ were ketonuric. Among these severe symptoms of keto-acidosis were seen in 14 patients, but nobody was unconscious. Ketonuria occurred with the same frequency in all groups.
Table 5. Total serum insulin (IRI) in relation to some HLA-types

\begin{tabular}{|c|c|c|c|c|c|c|}
\hline \multirow[b]{2}{*}{ HLA } & \multicolumn{6}{|c|}{$\mathrm{IRI} \mu \mathrm{U} / \mathrm{ml}$} \\
\hline & Total & $<300$ & $300-1000$ & $>1000$ & mean & SD \\
\hline B8 & 36 & $15^{\mathrm{a}}$ & 11 & 10 & 1356 & 2203 \\
\hline BW15 & 28 & $4^{\mathrm{a}}$ & 15 & 9 & 1551 & 2236 \\
\hline B8, W15 & 10 & 2 & 6 & 2 & 1490 & 2334 \\
\hline B7 & 14 & 6 & 5 & 3 & 580 & 640 \\
\hline B18 & 8 & 3 & 3 & 2 & 1236 & 1914 \\
\hline $\begin{array}{l}\text { All } \\
\text { patients }\end{array}$ & 94 & 27 & 39 & 28 & 1221 & 1854 \\
\hline
\end{tabular}

Measurable amounts of fasting C-peptide $(\geq 0.04$ $\mathrm{pmol} / \mathrm{ml}$ ) were found in 33 out of 94 patients $(34.7 \%$ ) with a mean value of $0.26 \mathrm{pmol} / \mathrm{ml}$ (range $0.04-2.30$, Table 3). Measurable C-peptide seemed to be less common in patients with HLA-B8, W15 $(\mathrm{p}<0.10)$ while patients with HLA-B18 had detectable C-peptide more often than the other groups $(p<0.02)$.

Insulin binding capacity of IgG is shown in Table 4. Antibodies $(\geq 0.050 \mathrm{mU} / \mathrm{ml})$ were found in all but 4 patients. Total serum insulin is shown in Table 5. In patients with HLA-BW15 high values of IgG were more common $(\mathrm{p}<0.05)$ and low values of both $\operatorname{IgG}$ $(p<0.05)$ and IRI $(p<0.05)$ less frequent than in the other groups. Patients with HLA-B 8 had the same mean value of $\mathrm{IgG}$ as the others but there were relatively more cases with low IRI values in this group $(\mathrm{p}<0.05)$. Furthermore, patients with HLA-B7 had significantly lower values of $\operatorname{IgG}(p<0.05)$ than the rest of the patients.

\section{Discussion}

Some alleles in the HLA-system are associated with certain diseases [22]. The HLA system is complex with at least four identified linked loci -3 serologi- 
Table 6. HLA-B8, HLA-BW15, and HLA-B7 in juvenile diabetes

\begin{tabular}{|c|c|c|c|c|c|c|c|c|c|}
\hline \multirow[b]{2}{*}{ Authors } & \multicolumn{3}{|c|}{ HLA-B8 } & \multicolumn{3}{|c|}{ HLA-BW15 } & \multicolumn{3}{|c|}{ HLA-B7 } \\
\hline & $\mathrm{n}$ & $\mathrm{RR}$ & $X^{2}$ & $\mathrm{n}$ & RR & $\mathrm{X}^{2}$ & $\mathrm{n}$ & $\mathrm{RR}$ & $X^{2}$ \\
\hline Present study & 102 & 2.64 & 17.29 & 102 & 1.33 & 1.45 & 102 & 0.40 & 9.06 \\
\hline Finkelstein et al. [8] & 28 & 1.67 & 1.26 & 28 & 2.89 & 2.84 & 28 & 0.85 & 0.12 \\
\hline Singal and Blajchman [27] & 50 & 1.26 & 0.31 & 50 & 5.06 & 13.28 & 50 & 0.94 & 0.02 \\
\hline Cudworth and Woodrow [6] & & & & & & & 50 & 0.40 & 4.98 \\
\hline Cudworth and Woodrow [7] & 150 & 2.17 & 14.20 & 150 & 2.34 & 9.30 & & & \\
\hline Thomsen et al. [29] & 85 & 2.60 & 18.11 & 85 & 2.25 & 11.59 & 85 & 0.32 & 10.23 \\
\hline Jansen et al. [11] & 109 & 1.99 & 10.06 & 109 & 1.78 & 5.70 & 109 & 0.42 & 8.63 \\
\hline Cathelineau et al. [4] & 55 & 4.19 & 14.00 & 55 & 0.91 & 0.04 & & & \\
\hline Schernthaner et al. [26] & 50 & 3.30 & 14.67 & 50 & 3.33 & 11.16 & & & \\
\hline Ludwig et al. [15] & & & & & & & 64 & 0.47 & 4.05 \\
\hline Total & 629 & & & 629 & & & 488 & & \\
\hline Combined RR & & 2.37 & & & 2.03 & & & 0.46 & \\
\hline $\mathrm{X}^{2}$ & & & 82.45 & & & 42.40 & & & 31.18 \\
\hline $\mathrm{p}$ & & & $<0.0001$ & & & $<0.0001$ & & & $<0.0001$ \\
\hline
\end{tabular}

cally defined (HLA A, B, C) and one lymphocyte defined (HLA-D). Most of the investigations dealing with HLA and disease have so far mainly included the serologically defined antigens and the associations found have only involved alleles of the $B$ locus. HLA-D locus is probably included among the immune response (Ir) genes [20]. The $\mathrm{D}$ locus is linked more closely to the B locus than to $\mathrm{A}$ and $\mathrm{C}$ loci, but increased $\mathrm{B}$ alleles are not always accompanied by an increase in D allele frequencies [21].

Table 6 compares the results of the present study with those of 9 previous studies with regard to the combined risks for HLA-B8, BW15 and B7 in juvenile diabetes $[4,6,7,8,11,15,26,27,29]$. All authors have found an increased frequency of HLA-B8 and the combined RR is significantly increased $(p<0.0001)$. There was a non-significant increase of BW15 in our study. However, this allele was more common in our reference group than in other reference groups. In all but one of the other studies mentioned in Table 6 an increased frequency of BW15 has been reported and the combined RR is significantly increased $(p<0.0001)$. In all studies the RR for HLA-B7 positive individuals is less than unity and the combined RR is significantly low ( $\mathrm{p}<$ 0.0001). Perhaps HLA-B7 is associated with a gene protective against juvenile diabetes [15].

In one of the 9 previous studies mentioned above D-typing was reported. RR for DW3 was found to be higher than RR for B8 [29].

In individuals with HLA-B8 certain virus infections have been suggested as provoking an immune response leading to destruction of the B-cells and an insulin dependent type of diabetes $[14,24]$. However, epidemiological studies have given divergent results $[1,25]$. In the present diabetic population there was no correlation between HLA-B8 and/or BW15 and the occurrence of infection within two months before onset of diabetes. On the other hand infections seemed to be less common before onset of diabetes in patients with HLA-B7.

As C-peptide and insulin are secreted from the $B$-cells in equimolar amounts, C-peptide has been used as a measure of the endogenous insulin production in insulin treated diabetics [2]. It has been generally accepted that in most cases of juvenile diabetes the production of insulin by the B-cells is either drastically reduced or totally eliminated shortly after the onset of the disease [19]. However, some juvenile diabetics have measurable amounts of C-peptide not only during but also after the early remission period [16], indicating some residual B-cell function. If HLA-B8 or other HLA-antigens were related to an immune response leading to destruction of B-cells and a more severe form of insulin dependent diabetes, one would expect minimal levels of serum C-peptide in patients with such HLA-antigens.

In this study patients with HLA-B8 and/or BW15 did not differ significantly from other patients with regard to the $\mathrm{C}$-peptide levels, but the results suggest that if both alleles of the B locus are occupied by diabetes predisposing genes, the RR of getting diabetes is higher, onset of diabetes seems to be earlier and B-cell damage more severe. The significantly increased incidence of measurable $\mathrm{C}$-peptide in the small group of patients with HLA-B18 (which occurred in normal frequency) may imply that this HLA antigen is combined with a milder form of diabetes. However, an alternative explanation is the somewhat shorter duration of diabetes among these patients (Table 3).

The high levels of insulin antibodies found in this study may be due to treatment with immunogenic insulins. However, the degree of antibody production may also be genetically determined and associated with certain histocompatibility genes [12]. The results 
of the present study (Table 4-5) support the hypothesis that a genetic mechanism may be involved. - As it has been demonstrated that high levels of insulin antibodies are negatively correlated to the level of C-peptide in juvenile diabetics beyond the early remission period [16], and also negatively correlated to the degree of metabolic control [17], it may be relevant to suppose that not only absence of endogenous insulin production but also high levels of insulin antibodies mean a more severe form as juvenile diabetes.

HLA-B8 positive patients do not seem to be predisposed to a more severe form of diabetes as far as can be seen from the determination of C-peptide levels and the levels of insulin antibodies. HLABW15 positive patients, however, might be predisposed to produce more insulin antibodies than others [11]. Individuals with HLA-B7 seem to have a diminished risk of getting juvenile diabetes, and in this study diabetics with HLA-B7 had lower levels of insulin antibodies. These results suggest that HLA-B7 and possibly HLA-B18 might be associated with a different and perhaps milder form of juvenile diabetes.

Acknowledgements. We wish to thank Mrs Gun Bjare, Mrs Eva Cornell, Miss Bente Hansen, Miss Marianne Knudsen and Miss Viola Selling for their excellent technical assistance.

\section{References}

1. Barbosa, J., Noreen, H., Goetz, F., Simmons, R., Najarian, J., Yunies, E. J.: Juvenile diabetes and viruses. Lancet 1976 I, 371

2. Block, M.B., Mako, M.E., Steiner, D.F., Rubenstein, A.H.: Circulating C-peptide immunoreactivity. Studies in normals and diabetic patients. Diabetes 21, 1013-1026 (1972)

3. Bøyum, A.: Separation of leukocytes from blood and bone marrow. Scand. J. clin. Lab. Invest. 21, (Suppl.) 97 (1968)

4. Cathelineau, G., Cathelineau, L., Hora, J., Schmid, M., Dausset, J.: HL-A and juvenile diabetes. Eleventh Annual Meeting of the European Association for the Study of Diabetes. Diabetologia 11, (Abstr.) 355 (1975)

5. Christiansen, Aa.H.: Radioimmunoelectrophoresis in the determination of insulin binding to IgG. Methodological studies. Horm. Metab. Res. 5, 147-154 (1973)

6. Cudworth, A.G., Woodrow, J.C.: HL-A system and diabetes mellitus. Diabetes 24, 345-349 (1975)

7. Cudworth, A.G., Woodrow, J.C.: Evidence for HL-A linked genes in "juvenile" diabetes mellitus. Brit. med. J. 1975 III, $133-135$

8. Finkelstein, S., Zeller, E., Walford, R.L.: No relation between HL-A and juvenile diabetes. Tissue Antigens 2, 74-77 (1972)

9. Heding, L.G.: Determination of total serum insulin (IRI) in insulin-treated diabetic patients. Diabetologia 8, 260-266 (1972)

10. Heding, L.G.: Radioimmunological determination of human C-peptide in serum. Diabetologia 11, 541-548 (1975)

11. Jansen, F.K., Bertrams, J., Jansen, F. K., Grüneklee, D., Drost, H., Reis, H.E., Bever, J., Kuwert, E., Gries, F. A., Altrock, E.: Genetic association of the insulin-antibody production with histocompatibility (HL-A)-antigens in diabetics. Eleventh Annual Meeting of the European Association for the Study of Diabetes. Diabetologia 11, (Abstr.) 352-353 (1975)
12. Kiesel, U., Jansen, F. K.: Influence of histocompatibility antigens and of "foreigness" of insulin on titre and heterogeneity of insulin antibodies. Eleventh Annual Meeting of the European Association for the Study of Diabetes. Diabetologia 11, (Abstr.) 355 (1975)

13. Kissmeyer-Nielsen, F., Kjerbye, K.E.: Lymphocytotoxic microtechnique. Purification of lymphocytes by flotation. In: Histocompatibility testing, pp. 381-383. Copenhagen: Munksgaard 1967

14. Leading article: Autoimmune diabetes mellitus. Lancet 1974 II, 1549-1551

15. Ludwig, H., Schernthaner, G., Mayr, W.R.: Is HLA-B7 a marker associated with a protective gene in juvenile-onset diabetes mellitus? New. Engl. J. Med. 294, 1066 (1976)

16. Ludvigsson, J., Heding, L.G.: C-peptide in children with juvenile diabetes. A preliminary report. Diabetologia 12, 627-630 (1976)

17. Ludvigsson, J., Heding, L. G., Larsson, Y., Leander, E.: C-peptide in juvenile diabetics beyond the postinitial remission period. - Relation to clinical manifestations at onset of diabetes, remission and diabetic control. Acta paediat. scand. (To be published)

18. Löw, B., Scherstén, B., Sartor, G., Thulin, T., Mittelman, F.: HLA-A 8 and $W 15$ in diabetes mellitus and essential hypertension. Lancet 1975 I, 695

19. Marble, A., White, P., Bradley, R. F., Krall, L.P., (eds): Joslin's diabetes mellitus. 11 ed. Philadelphia: Lea and Febiger 1971

20. McDevitt, H.O., Bodmer, W.F.: HL-A, immune-response genes and disease. Lancet 1974 I, 1269-1275

21. Möller, E., Hammarström, L., Smith, E., Matell, G.: HL-A8 and $\mathrm{LD}-8 \mathrm{a}$ in patients with myasthenia gravis. Tissue Antigens 7, 39-44 (1976)

22. Möller, G., (ed): Transplant. Rev. 22, 1975

23. Nerup, J., Ortved Andersen, O., Christy, M., Platz, P., Thomsen, M., Svejgaard, A., Botazzo, F., Pouplard, A., Doniach, D.: HL-A factors, autoimmunity, virus and juvenile diabetes mellitus. Eleventh Annual Meeting of the European Association for the Study of Diabetes. Diabetologia 11, (Abstr.) 365-366 (1975)

24. Nerup, J., Platz, P., Ortved Andersen, O., Christy, M., Lyngsøe, J., Poulsen, J. E., Ryder, L.P., Thomsen, M., Staub Nielsen, L., Svejgaard, A.: HL-A antigens and diabetes mellitus. Lancet 1974 II, 864-866

25. Rolles, C.J., Rayner, P.H.W., Mackintosh, P.: Aetiology of juvenile diabetes. Lancet 1975 II, 230

26. Schernthaner, G., Mayr, W.R., Pacher, M., Ludwig, H., Erd, W., Eibl, M.: HL-A8, W15 and T3 in juvenile-onset diabetes mellitus. Horm. Metab. Res. 7, 521-522 (1975)

27. Singal, D.P., Blajchman, M.D.: Histocompatibility (HL-A) antigens, lymphocytotoxic antibodies and tissue antibodies in patients with diabetes mellitus. Diabetes 22, 429-432 (1973)

28. Svejgaard, A., Jersild, C., Staub-Nielsen, L., Bodmer, W.F.: HL-A antigens and disease. Statistical and genetical considerations. Tissue Antigens 4, 95-105 (1974)

29. Thomsen, M., Platz, P., Orved Andersen, O., Christy, M., Lyngsøe, J., Nerup, J., Rasmussen, K., Ryder, L.P., Staub Nielsen, L., Svejgạard, A.: MLC typing in juvenile diabetes mellitus and idiopathic Addison's disease. Transplant. Rev. 22, 125-147 (1975)

30. Thorsby, E.: Cell specific and common antigens on human granulocytes and lymphocytes demonstrated with cytotoxic heteroantibodies. Vox Sang. (Basel) 13, 194-206 (1967)

Received: June 8, 1976, and in revised form: September 28, 1976

Dr. J. Ludvigsson

Linköping Univ.

Dept. of Pediatrics

S-581 85 Linköping

Sweden 